\title{
EVALUATING THE ROLE OF INSURANCE IN
} MANAGING RISK OF FUTURE PANDEMICS

\author{
Howard Kunreuther \\ Jason Schupp \\ Working Paper 28968 \\ http://www.nber.org/papers/w28968
NATIONAL BUREAU OF ECONOMIC RESEARCH
1050 Massachusetts Avenue
Cambridge, MA 02138
June 2021

We thank Alex Braun, Ben Collier and Carolyn Kousky for helpful comments on an earlier draft. The views expressed herein are those of the authors and do not necessarily reflect the views of the National Bureau of Economic Research.

NBER working papers are circulated for discussion and comment purposes. They have not been peer-reviewed or been subject to the review by the NBER Board of Directors that accompanies official NBER publications.

(C) 2021 by Howard Kunreuther and Jason Schupp. All rights reserved. Short sections of text, not to exceed two paragraphs, may be quoted without explicit permission provided that full credit, including (O) notice, is given to the source. 
Evaluating the Role of Insurance in Managing Risk of Future Pandemics

Howard Kunreuther and Jason Schupp

NBER Working Paper No. 28968

June 2021

JEL No. D81,D91,G22,H84

\begin{abstract}
$\underline{\text { ABSTRACT }}$
COVID-19 has demonstrated the challenges that policymakers, insurers, businesses, and employees face when disaster assistance programs are developed after the pandemic has already started. There is now an opportunity to design and implement effective and efficient solutions to manage the financial risks of a future pandemic. This paper suggests a practical framework, informed by the recent experience with COVID-19, for defining a meaningful role for insurance in managing business interruption (BI) and other risks from future pandemics. Policymakers, regulators, businesses, and other stakeholders interacting with representatives from the insurance industry can assist in defining its role in providing protection against the financial consequences of future pandemics. This framework, while designed for dealing with future pandemics, may be applied to other catastrophic and systemic risks.
\end{abstract}

\author{
Howard Kunreuther \\ Wharton Risk Management \\ and Decision Processes Center \\ The Wharton School \\ University of Pennsylvania \\ 3819 Chestnut Street, Suite 330 \\ Philadelphia, PA 19104-6366 \\ and NBER \\ kunreuth@wharton.upenn.edu \\ Jason Schupp \\ Centers for Better Insurance, LLC \\ 9006 Bush Creek Circle \\ Frederick, MD 21704 \\ jason.schupp@betterins.org
}




\section{Introduction}

The COVID-19 pandemic has proven to be one of the most extensive and complex catastrophic risks the global economy has ever faced. This paper provides stakeholders with a practical framework, informed by the recent experience with COVID-19, for defining a meaningful role for insurance in managing business interruption (BI) and other risks from future pandemics (“pandemic risk”). In particular, this framework puts into context the scale and complexity of the pandemic risk by comparing and contrasting it with other extreme events such as floods, earthquakes and terrorism.

We discuss the following three alternative options where the property and casualty industry may be able to play a role in supporting businesses, nonprofits, and the public sector in managing the risk of future pandemics in the United States:

1. Status Quo (SQ) - Currently, private insurers provide certain coverages that may respond to pandemic losses (e.g., workers compensation, liability, surety, and event cancellation), with the public sector providing ex post relief to businesses and individuals. SQ contemplates a continuation of these mechanisms during future pandemics.

2. Service Provider (SP) - This option contemplates a non-risk-bearing role for the property and casualty insurance industry. Insurers would provide underwriting expertise, marketing of pandemic risk-related products, and claims payment administration on a fee-for-service basis. The entire cost of pandemic-related claims would be publicly financed. 
3. Service and Risk (SR) - In addition to its role as a service provider as characterized by SP, property and casualty insurers would commit capital - without imperiling the financial viability of the insurance industry - to cover a specified layer or other defined element of losses from a future pandemic. SR contemplates that insurers would price pandemic risk coverage, thereby sending economic signals for incentivizing loss reduction measures.

The paper then proposes three guiding principles, a decision-making framework, and a number of practical questions for evaluating the performance of each of these alternative options (SQ, SP, and SR) in future pandemics, including a hypothetical reoccurrence of COVID-19. This framework, while designed for dealing with future pandemics, may be applied to other catastrophic and systemic risks.

To set the context for this discussion, there are two fundamental characteristics of the pandemic risk that necessitate a public response:

- The scale, correlations, and complexity of pandemic risk, as evidenced by ongoing COVID-19 losses, far exceed traditional parameters that define the concept of insurability for private insurers and reinsurers as noted in Section II;

- The property and casualty insurance industry's financial capacity for covering foreseeable losses from future pandemics is inadequate so that substantial public sector participation in financing pandemic losses will be necessary as noted in Section I. 


\section{I: Scale and Complexity of the Pandemic Risk}

The United States' experience in responding to COVID-19 suggests that the scale and complexity of the pandemic risk is greater than that of other extreme events for which privatepublic partnerships have been established.

Scale -The United States government's response highlights the magnitude of the pandemic challenge facing the country. For example, during the months of April to June 2020, the Paycheck Protection Program (PPP), a federally funded 8-week small business program, approved more than 5 million applications for forgivable loans representing some $\$ 525$ billion in pandemic relief. This banking-administered relief effort eclipses the scale of any historical insurance-based catastrophe response: PPP’s outlay between April and June 2020 was more than twice the amount of U.S. property insurance claims from the ten largest property insurance loss events combined, or the equivalent of 170 years of insurance premiums associated with the Terrorism Risk Insurance Act, as shown in Figure 1. This allotment of PPP funds is the first of a number of federal and state relief programs directed to individuals, businesses, nonprofits, and local governments. With the passage of the American Rescue Plan Act signed by President Biden on March 11, 2021, the expenditures by the public sector for COVID-19 relief now total more than $\$ 3$ trillion. ${ }^{1}$ 


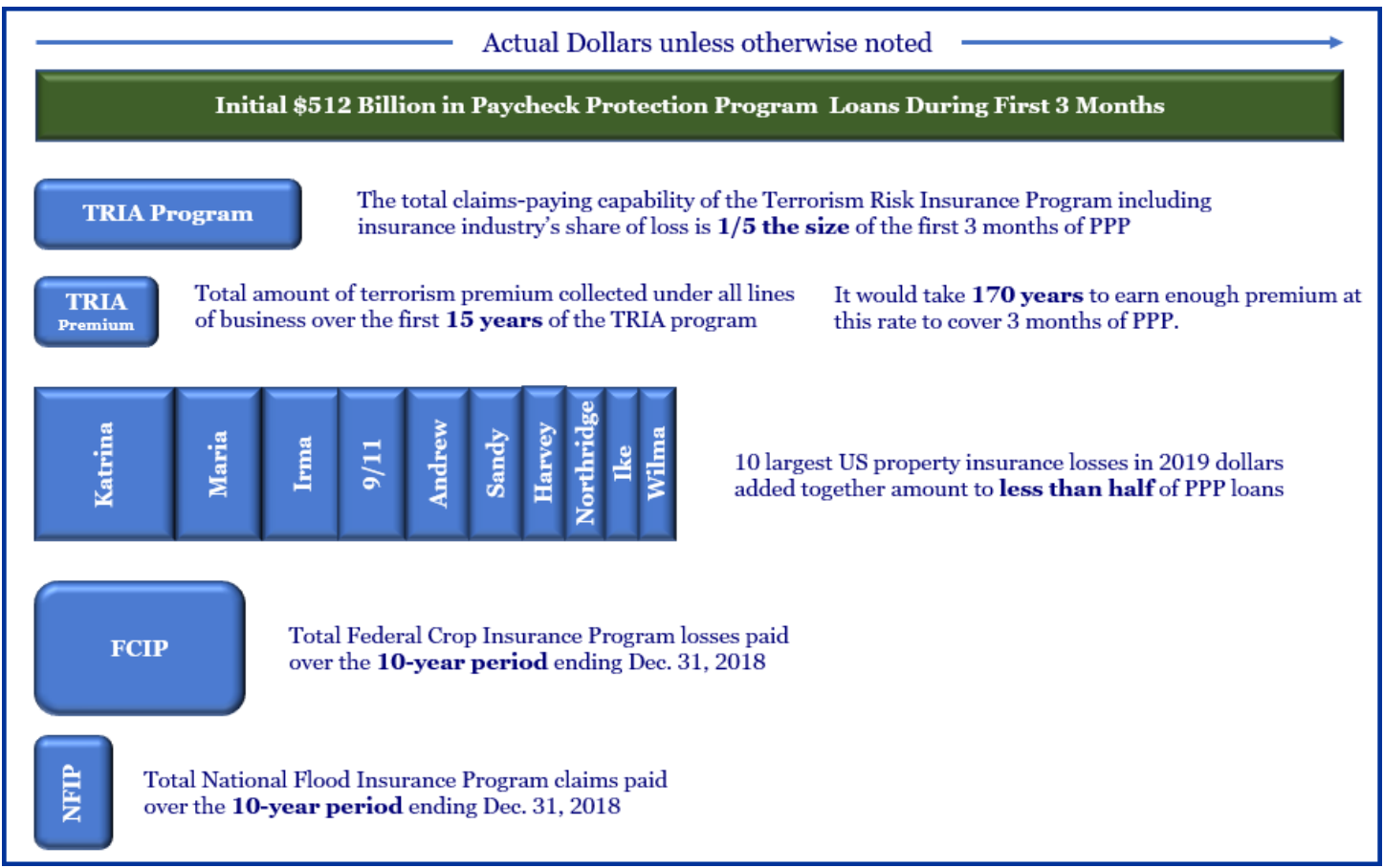

Sources: U.S. Treasury Paycheck Protection Program Loan Data; Insurance Information Institute data regarding U.S. Catastrophes; and U.S. Treasury's Report on the Effectiveness of the Terrorism Risk Insurance Program.

\section{Figure 1. Paycheck Protection Program (PPP) Expenditures (APril-June 2020) Compared to Historical InSURED LoSSES AND OTHER PROGRAM DiMENSIONS}

Complexity - Businesses, nonprofits and governments face a dynamic catalogue of exposures from COVID-19, as shown in Table 1. Future pandemics would likely present similar risks and exposures (e.g., event cancellation and surety) as well as other losses that have yet to emerge that could take years or even decades to fully understand.

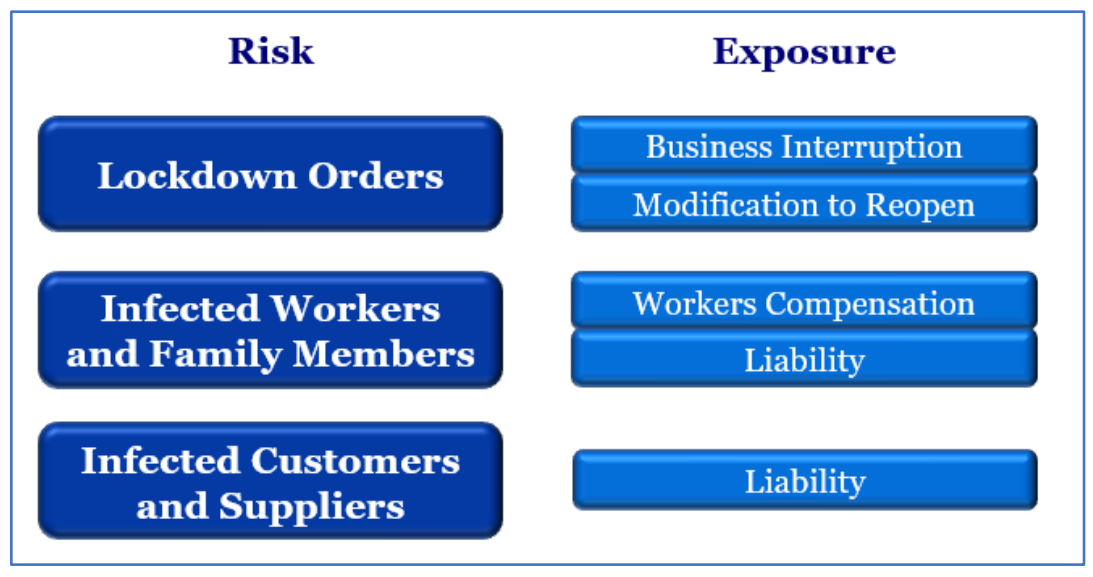

TABle 1. Risk AND EXPOSURES From FUtURe PANDEMics 


\section{II: Parameters of Insurability}

Insurability depends on the following criteria (Hartwig and Gordon 2020):

- A risk must consist of a large number of exposure units so that the losses of the few can be distributed across the entire population of policyholders;

- Losses must be accidental or random and unintentional in nature;

- Losses must be determinable and measurable, enabling accurate and timely adjustment;

- Losses cannot be exceedingly catastrophic or financially ruinous to the risk pool as a whole;

- The probability of loss and its consequences must be calculable, a characteristic necessary for the proper modeling and pricing of risk; and

- The premium charged by insurers to transfer the risk of loss must be economically affordable.

Rather than a binary choice with respect to a risk (i.e., insurable or uninsurable), there is a continuum of insurability, ranging from easy-to-insure to difficult-to-insure. The U.S. experience in dealing with COVID-19 shows that pandemic risk is toward the far end of that spectrum. That said, there are steps that can be taken to nudge the pandemic risk toward a greater degree of insurability, such as:

- Containing the probability and severity of risk: COVID-19 and earlier pandemics (e.g., the “Spanish” Flu (1918-20), Hong Kong Flu (1968), Asian Flu (1956-1958), H1N1 Flu (2009)) provide data that insurers can utilize to estimate probability and potential losses and deaths from future pandemics of different magnitudes. Catastrophe models with respect to pandemics are still in their infancy, but they could eventually be used to 
complement historical data as a basis for pricing insurance. ${ }^{2}$ Because statistical information on prior pandemics is extremely limited, insurers would likely incorporate risk margins in their premium calculations resulting in higher prices and reduced capacity.

Despite its severity, COVID-19 can be viewed as mild compared to the 1918 "Spanish" Flu pandemic. The current pandemic has killed over 3.75 million people worldwide as of June 9, 2021. John Barry (2004) noted that the number of fatalities in the $1918 \mathrm{flu}$ pandemic is estimated to be between 50 and 100 million. In a January 2021 interview, he pointed out that adjusting for population, the number of fatalities today would be equivalent to between 225 and 450 million people. ${ }^{3}$ The impact of future pandemics on the insurance industry is discussed in a Lloyd's (2008) report. This report emphasizes that any insurance proposal must be designed to withstand a more severe pandemic than COVID-19.

- Capping potentially ruinous exposure: Following the SARS outbreak in 2003, even though insured losses from that event were modest, insurers identified the potentially unmanageable severity of the pandemic risk and thus excluded losses due to business interruption, property damage and liability in most of their commercial policies. As a result, pandemic exclusions were widely in place with respect to certain products and markets for years prior to the outbreak of COVID-19.

\footnotetext{
${ }^{2}$ https://www.businessinsurance.com/article/20210510/NEWS06/912341730/Underwriters-puzzle-over-how-tomake-pandemics-insurable-again-Scor-Zurich-Insur

${ }^{3}$ https://www.ama-assn.org/delivering-care/public-health/author-john-barry-talks-about-1918-flu-pandemic-andcovid-19
} 
The U.S. experience with COVID-19 affirms the potential of extreme losses from pandemics. A private-public partnership, such as a federal backstop or similar mechanism would cap overall exposure of the pandemic risk to the insurance industry and create a limited private market for covering well-defined and limited amounts of losses from future pandemics.

- Dealing with affordability: The public sector could assist businesses and other entities that cannot afford a risk-based insurance premium through means-tested vouchers, tax credits or other subsidies.

\section{III: Private-Public Partnerships in Response to Other Extreme Risks}

History shows that many insurers have been willing to provide coverage against extreme risks perceived as having a low probability of large claims payments. After suffering a severe loss from an "unexpected” extreme event, insurers may increase premiums significantly (if allowed to do so by state regulators), reduce the amount of protection they are willing to offer through higher deductibles and/or lower limits of coverage, or conclude that the risk is uninsurable.

Aware of these issues, the industry and policymakers at the federal and/or state level have sometimes established and continuously refine a private-public partnership to assist in managing extreme risks, as illustrated by the following examples:

- Flood insurance was offered by many insurers from the 1890s until 1928, when two severe floods led every responsible company to discontinue coverage, declaring the flood risk to be uninsurable (Knowles and Kunreuther 2014). The National Flood Insurance 
Program (NFIP) was established in 1968 to provide homeowners in flood-prone areas with financial protection against damage to their property. Currently, most residential flood policies in the United States are provided by the NFIP, with private insurers marketing coverage and processing claims but not bearing any risk.

- Earthquake insurance was widely available to homeowners in California starting in 1916 but few homeowners purchased coverage. Following the Loma Prieta earthquake in 1989 and the Northridge quake of 1994, there was increased interest by homeowners in earthquake-prone areas of California in purchasing earthquake insurance. In 1995, insurers concluded that they could not risk selling more residential earthquake policies. This led to the formation of the California Earthquake Authority (CEA), a state-created entity that has offered earthquake insurance since that time (Roth, Jr. 1998).

- Terrorism coverage was provided by insurers on commercial property policies until after the attacks of September 11, 2001. Insurers generally had not evaluated how much to charge for this protection, despite the World Trade Center attack in 1993 and the Oklahoma City bombing in 1995, because they had not suffered severe losses from those events. Following 9/11 most insurers refused to include terrorism as part of their commercial property coverage—especially in central business districts—or they charged extremely high premiums (Kunreuther, Pauly and McMorrow 2013). This market reaction led Congress to enact the Terrorism Risk Insurance Act of 2002 (TRIA), a private-public partnership that has been renewed four times. 


\section{Addressing the Pandemic Risk}

Insurers currently face a multifaceted push by policyholders, state legislatures, U.S. Congress, the courts, and public opinion for some kind of an "insurance solution” to COVID-19 and future pandemics. In proposing a role that insurance can play with respect to the pandemic risk it is appropriate to consider:

- Broad stakeholder participation (e.g., insurer, policyholder, and public sector interests) to ensure identification and definition of the economic and societal problems to be solved;

- The potentially strong correlation between pandemic risk exposure and asset values (meaning that a pandemic is an exposure that impacts both sides of an insurer's balance sheet);

- The extent and potential volatility of reinsurance participation in protecting insurers against the pandemic risk and diversifying the risk globally;

- The capacity of insurers to commit to delivering administrative services (e.g., claims management) and to incur risk-bearing with due concern for the industry’s concurrent role in insuring against non-pandemic exposures;

- The public policy objectives associated with the risk of future pandemics that fall outside of the purview of the property and casualty insurers but may have an impact on the size of BI losses or its larger economic consequences such as:

o Assisting employees temporarily laid off, through programs such as expanded unemployment insurance;

o Considering measures adopted by other countries, such as the Short Time Work (Kurzarbeit) program in Germany, where companies paid temporarily laid-off employees a significant portion of their salary for up to one year and these companies were then reimbursed by the German government; 


\section{V: Design Options and Proposals for Private-Public Partnerships for Pandemic Risk}

The need to consider private-public partnerships for accelerating economic recovery from COVID-19 and providing protection against future pandemics is the basis for a report by Marsh (2020) that emphasizes the importance of examining the role of the insurance industry in concert with the public sector. The three alternative options for dealing with the pandemic risk noted above are now discussed in more detail, with reference to some bills and proposals with respect to the role that insurance could play for covering the costs associated with the outbreak of a future pandemic. ${ }^{4}$

1: Maintain the Status Quo (SQ). Under this option, private insurers would cover some pandemic losses with the public sector providing ex post relief to businesses and their employees. For example, individual states may adopt some form of presumption of entitlement to workers compensation benefits or put limitations-on third-party liability. Because insurance is regulated at the state level, responses are likely to differ considerably state-by-state.

During 2020, bills were introduced in Ohio, ${ }^{5}$ Massachusetts ${ }^{6}$ and New Jersey ${ }^{7}$ that would invalidate existing virus or pandemic exclusions. None were enacted, although new introductions of similar bills are expected during the 2021 state legislative sessions. Under the Ohio proposal, insurance policies issued to businesses employing 100 or fewer workers would cover pandemicrelated BI notwithstanding any virus exclusion or property damage requirement in the contract. Insurers paying these claims could seek reimbursement from the state’s BI Insurance Fund, financed through assessments levied on insurers in proportion to their share of annual statewide

\footnotetext{
${ }^{4}$ For a detailed analysis of five of these proposals, see Dixon and Morikawa, 2021.

${ }^{5}$ Ohio House Bill 589 introduced March 24, 2020.

${ }^{6}$ Massachusetts Senate Bill 2655 introduced April 6, 2020.

${ }^{7}$ New Jersey Assembly Bill No. 3844 introduced March 16, 2020.
} 
property and casualty premiums. By way of comparison, the Massachusetts proposal would apply to employers of 150 or fewer workers. Insurers required to pay excluded pandemic BI claims could apply for reimbursement from the state Insurance Commissioner via assessments on insurers selling BI insurance in Massachusetts.

Bisco et al. (2020) conclude that even if insurers are successful in arguing that current policies do not cover BI losses from pandemics, they will likely incur significant legal expenses in defending denial-of-coverage and bad-faith lawsuits brought by policyholders.

2: Service Provider Model (SP). Under this option, the insurance industry plays an administrative, non-risk-bearing role in the program with insurers providing some or all underwriting, claims, distribution and other capabilities on a fee-for-service or similar basis. For example, insurance agents and brokers may elect to sell a federally administered expense protection agreement to businesses and nonprofits; a business that purchased this protection and was later ordered closed due to a pandemic would receive an immediate payout of a previously determined amount. The most prominent proposal suggesting this approach is the Business Continuity Protection Program (BCPP). ${ }^{8}$

3: Service and Risk Model (SR). This option combines the insurance industry's administrative function described in SP together with a risk-bearing role. The property and casualty insurance industry would insure a limited layer or other well-defined element of the pandemic risk without jeopardizing their financial viability. The public sector would limit the pandemic risk for

${ }^{8}$ APCIA Press Release, Insurance Trades Unveil Federal Pandemic Solution May 21, 2020. 
insurers, distribute the overall cost of the program and assist small businesses in purchasing coverage for pandemic risk through means-tested vouchers or tax credits.

An example of this option is the Pandemic Risk Insurance Act (PRIA) introduced in May 2020 but not advanced before the end of the Congressional session. ${ }^{9}$ This proposal relied on the approach developed for the terrorism risk after 9/11 (TRIA). Under this proposal, the private sector (insurers) would provide coverage for BI losses with a federal backstop reimbursing catastrophic losses that exceeded the ability of the private sector to insure. As Klein and Weston (2020) note, PRIA would raise equity issues, and could obligate the government to make payments to businesses that would not be adequately funded by the program. Furthermore, based on TRIA take-up rates, it is unclear how many businesses would buy coverage offered by insurers.

\section{VI: Guiding Principles}

The decision framework for evaluating the alternative options hinges upon the following three guiding principles:

Principle 1: Charge risk-based premiums to the extent possible. Premiums that reflect risk from future pandemics provide businesses with signals as to the nature of the hazard they face and, to the extent feasible, encourage organizations to engage in cost-effective mitigation measures to reduce their vulnerability and their insurance expenses. Risk-based premiums would reflect the insurers' cost of capital to ensure an adequate return to their investors. Based on this principle:

${ }^{9}$ H.R.7011, 116 ${ }^{\text {th }}$ Congress, introduced May 26, 2020 that has not been enacted. 
- State insurance regulators would allow insurers to charge premiums against losses from future pandemics that reflect the best estimate of the risk and the cost of capital;

- State insurance regulators would continue to ascertain whether insurers and reinsurers have sufficient capital, so they are unlikely to become financially impaired or insolvent following a future pandemic; and

- Insurers would consider offering premium reductions to firms that adopted appropriate standards (e.g., workplace safety precautions) that mitigate the severity of the pandemic risk.

Principle 2: Deal with fairness and affordability issues. Businesses that cannot afford riskbased insurance premiums would be given financial assistance to purchase insurance:

- Specific means-tested criteria could determine who qualifies for this funding; and

- Funding for this protection could come from public funding such as vouchers or tax reductions, rather than through insurance subsidies or distorting premiums such that some businesses were not charged risk-based rates.

Principle 3: Develop risk management strategies prior to the next disaster. To reduce losses and illnesses from a future pandemic, the public sector would develop and enforce regulations and standards, coupled with the following programs to enable firms to keep employees on payroll and re-employ them as the pandemic subsides:

- Regulations by the public sector (federal, state and local government) that require businesses to close and residents to shelter-in-place

- Requirements for social distancing and mask-wearing; and 
- Programs that provide funding to workers who are temporarily unemployed and to firms that are in danger of failure.

\section{VII: Pricing Insurance against Pandemic Risk}

The success of any private-public partnership for pandemic risk will be measured on available capacity (the nature and amount of coverage) as well as price (the affordability of that coverage). Empirical evidence supports the hypothesis that insurers will set higher premiums when faced with ambiguous probabilities and uncertain losses than they would for a well-specified risk. When underwriters were presented with scenarios where the probability and losses from an earthquake were ambiguous, they priced the premium between 43 and 77 percent higher than if the risks for this same disaster were well-specified (Kunreuther et al. 1993). Because the risk of a future pandemic and its consequences are even more ambiguous than for earthquakes, it is likely that underwriters would price the premium higher, relative to a well-specified risk.

In addition, there may be considerable differences in the premiums set by underwriters even when they are given the same information on the nature of the risk due to noise. When underwriters in a well-known insurance firm were asked to set premiums on a specific risk, the median difference in their estimates 55 percent. In other words, if the average premium across underwriters was $\$ 10,000$, another underwriter was likely to recommend a premium in the range of $\$ 4,500$ to $\$ 15,500$. There may have been many reasons why underwriters differed from each other, but the impact on the firm was a potential loss of millions of dollars (Kahneman et al. 2021).

Following a severe loss that impacts their balance sheet, insurers may be reluctant to offer coverage in the future. This behavior is consistent with the availability heuristic, highlighting the 
importance of salient information in estimating the likelihood of an event (Kahneman and Tversky 1973). Other biases or heuristics that can play a role are optimism, underestimating the risk; myopia, focusing on obtaining short run returns instead of long-term impacts; amnesia, forgetting the lessons of past disasters; and herding, the tendency to base choices on the observed actions of others (Meyer and Kunreuther 2017).

To deal with these issues, decision makers could utilize a checklist that requires them to consider the risks they face more systematically. ${ }^{10}$ Examples relevant for insurers include:

- Carefully consider the potential for extreme events rather than assuming "it will not happen to us";

- Quantify the firm's risk appetite and tolerance for taking on risks;

- Reframe the probability of an extreme event's occurrence over the next 30 years rather than next year; and

- Gain insights from near misses.

\section{VIII: A Framework for Evaluating Proposed Strategies}

A decision-making framework to evaluate the three alternative strategies involves the following elements depicted in Table 2:

- Options under consideration (the three alternatives noted above);

- Events (i.e., hypothetical pandemics) that affect the performance of each of the options. These $n$ distinct events, denoted as $E_{1}, E_{2}, \ldots, E_{n}$, are scenarios characterizing the nature of future pandemics based on data from past pandemics and future projections. One of

\footnotetext{
${ }^{10} \mathrm{An}$ expanded list of steps for dealing with catastrophic risk are highlighted in Kunreuther, H. and Useem, M. Mastering Catastrophic Risk (2021) based on a study of large publicly traded firms in the U.S and abroad.
} 
these events could be COVID-19. Epidemiologists and other experts can provide estimates of the likelihood and uncertainty associated with each of these events;

- Consequences of each Event $i$ if Option $j$ is chosen, denoted as $C_{i j}$, indicates the consequences when Option $O_{i}$ is chosen and Event $\mathrm{E}_{j}$ occurs. The consequences reflect impacts to the different interested parties (e.g., insurers, businesses/firms, employees, taxpayers, and the public sector - communities, state, regional, federal) as a function of the option chosen and specific pandemics that could occur. Suppose event 1 was COVID-19. Then $\mathrm{C}_{11}$ would be the impacts of COVID-19 if one maintained the Status Quo; $\mathrm{C}_{21}$ would be the impacts if insurers had a Service Provider role; $\mathrm{C}_{31}$ would be the impacts if insurers had a Service and Risk role as part of private-public partnership.

\section{Events}

\begin{tabular}{|l|l|l|l|l|l|l|}
\cline { 2 - 7 } \multicolumn{1}{c|}{} & $E_{1}$ & $E_{2}$ & $\cdots$ & $E_{j}$ & $\ldots$ & $E_{n}$ \\
\hline $1 S Q$ & $C_{11}$ & $C_{12}$ & $\cdots$ & $C_{1 j}$ & $\cdots$ & $C_{1 n}$ \\
& & & $\cdot$ & & $\cdot$ & \\
\hline $2 S P$ & $C_{21}$ & $C_{22}$ & $\cdots$ & $C_{2 j}$ & $\ldots$ & $C_{2 n}$ \\
\hline $3 S R$ & $C_{31}$ & $C_{32}$ & $\begin{array}{l}. \\
.\end{array}$ & $C_{3 j}$ & $\cdots$ & $C_{3 n}$ \\
\hline
\end{tabular}

\section{Options}

TABLE 2. FRAMEWORK FOR LINKING OPTIONS AND EVENTS WITH CONSEQUENCES

The options can be evaluated as to how they would perform in dealing with pandemics of any severity. The framework can also assess variations of the options and evaluate their impacts on other projected pandemics. The credibility of such an analysis depends on the accuracy of the assumptions for evaluating the different consequences for each of the options in the context of COVID-19 or future pandemics. 


\section{IX: Practical Issues}

To facilitate interaction among insurers and other interested parties such as regulators, legislators, and businesses regarding the potential role of the insurance industry in managing the risk of future pandemics, the following practical issues must be considered:

\section{The criteria for providing pandemic relief}

Much attention has focused on the financial challenges facing businesses that were "lockeddown” due to pandemic orders at the state or local levels. As a result, proposals such as BCPP and PRIA would provide BI insurance that pays benefits only to firms that have been locked down by governmental order. However, empirical evidence suggests that using lockdown orders as a basis for providing pandemic relief loans or as a criterion for providing insurance benefits is likely to leave out many impacted employers.

Traditional BI insurance compensates for a business’s lost income and continuing expenses incurred from an event that causes loss or damage to the insured property, such as from a flood, hurricane, earthquake or a terrorist attack. In contrast, the economic impact of a pandemic may be felt just as severely by businesses that are not ordered to close as those that are. Moreover, this economic impact is likely to extend over a protracted period and vary from region to region and industry to industry, so using a lockdown order as a criterion for an insurance benefit is likely to be inappropriate. ${ }^{11}$

\footnotetext{
${ }^{11}$ A statistical analysis of the PPP data revealed that the loan amount per capita is similar across states whether they are locked down, partially locked down or not locked down at all.
} 
An effective pandemic relief program would contemplate a range of criteria in assessing the need for financial assistance to firms and employees, including:

- Decline in revenue / Lower profits or losses

- Continuation of fixed expenses (e.g., rent, mortgage payments, utility expenses)

- Unemployment / Reduced working hours

- Cost of childcare during school closures

In assessing the effectiveness of a proposed program, stakeholders would have the opportunity to consider the financial relief to be delivered during a pandemic and the recovery period, bearing in mind:

- The purpose and amount of the benefits to be provided to businesses, nonprofits and local municipalities and the cost of these benefits over time; and

- The parties who could bear the costs of these benefits over relevant time periods as a function of the severity of the pandemic and its impacts.

\section{Evaluate, improve, or set aside existing COVID-19 pandemic relief programs}

State and federal policymakers have utilized a wide array of programs and policies for dealing with the economic consequences of the COVID-19 pandemic. The dialogue among stakeholders could evaluate which programs might remain following future pandemics, which programs require improvement, and which programs could be abandoned. Potential programs and policies to consider include:

- expanded eligibility for unemployment benefits

- increased unemployment benefit amounts 
- economic Impact Payments to individuals

- expanded leave entitlements for employees

- the Paycheck Protection Program, the Emergency Capital Investment Program, the Coronavirus Relief Fund, and the Coronavirus Economic Relief for Transportation Services Program

- limitations on or immunity from liability for healthcare providers, businesses and others with respect to injury caused by exposure to COVID-19

- presumption of compensability under state workers' compensation systems for medical expenses, wage loss and permanent or temporary disability from contracting COVID-19.

\section{Identify the role the insurance industry is best positioned to play}

With an understanding of what worked and what did not during COVID-19, the dialogue among stakeholders can focus on the potential to expand the role of the insurance industry as part of a private-public partnership for addressing future pandemic risks. Questions to be considered include:

- How and to what extent can the insurance industry fill gaps in the existing set of programs and policies?

- How and to what extent can the insurance industry augment the effectiveness of an existing program or policy?

- What existing programs or policies might insurance or an insurance administered solution replace? 
The proposed framework and guiding principles set forth in this paper are designed to foster a productive dialogue on appropriate roles for the insurance industry and public sector in addressing losses from future pandemics. An issue brief by the National Association of Insurance Commissioners (NAIC) (2021) states that it "supports Congress passing legislation establishing a forward-looking federal mechanism to help ensure widespread availability of business interruption insurance for pandemic risks without jeopardizing the financial condition of the insurance sector or undermining state insurance consumer protection.” As noted in a recent report by Lloyd’s (2020), “COVID-19 has set in motion irreversible societal change, calling for new insurance solutions.” The importance and opportunity to address this issue now, while it is still high on everyone’s agenda, cannot be overemphasized.

\section{X: Insurance against Catastrophic and Systemic Risks}

The need to prepare for future pandemics offers an opportunity to examine the role of insurance in providing protection and reducing losses from other catastrophic and systemic risks facing society today. Implementable risk management strategies will need to focus on efficiently and equitably distributing responsibility for reducing future losses and aiding the recovery process. Lowering the costs of future disasters through investments in loss reduction measures will increase the insurability of the risk. Figure 2 depicts a schema for insuring future catastrophe losses with the private and public sectors incentivizing or requiring mitigation measures and addressing fairness and affordability concerns. 

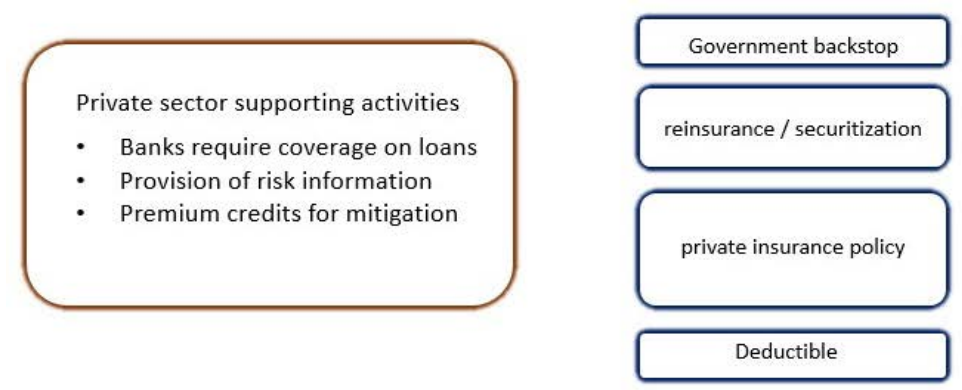

Public sector supporting activities

- Means-tested assistance program

- Building codes and land use regulations

- Funding for risk reduction

Note: The size of the boxes is not necessarily proportional to the amount of coverage in each layer. Figure adapted from Kousky and Kunreuther (2018).

\section{Figure 2. MANAging Future CATASTROPhic Risks}

As depicted in the bottom layer of the middle panel of Figure 2, the property owner or commercial enterprise would be responsible for the first layer of losses through a deductible, which reduces moral hazard and creates an incentive to reduce losses. Higher deductibles would lower insurance premiums for those able to self-insure a higher portion of their losses. The second layer of losses would be covered by private insurance with premiums reflecting risk. Banks and financial institutions could require this coverage as a condition for a loan or mortgage. The public sector could provide assistance to those in need. The next layer of losses would be covered through private reinsurance or other forms of risk transfer.

The top layer of losses would then be covered by the public sector. Coverage at the federal level could involve ex ante premiums or ex post assessments to recoup some or all of the public expenditures. The attachment point for public sector payments needs to be carefully determined so the private market is encouraged to bear as much risk as feasible. This would require a detailed market evaluation and ongoing adjustment over time. As shown in the right-hand and left-hand boxes in Figure 2, the public and private sectors would both need to engage in supportive activities to ensure comprehensive risk management. 


\section{XI: Conclusion}

COVID-19 has demonstrated the challenges that policymakers, insurers, businesses, and employees face when disaster assistance programs are developed after the pandemic has already started. There is now an opportunity to design and implement effective and efficient solutions to manage the financial risks of a future pandemic. Policymakers, regulators, businesses, and other stakeholders interacting with representatives from the insurance industry can assist in defining an appropriate role for insurance to play in providing protection against the financial consequences of future pandemics.

\section{References}

Barry, J. (2004). The Great Influenza: The Story of the Deadliest Plague in History. New York, NY: Viking Press.

Bisco, J, S. Fier, and D. Pooser (2020). Business Interruption Insurance and COVID-19: Coverage and Issues and Public Policy Implications. Journal of Insurance Regulation 39(5): 1-24. https://content.naic.org/sites/default/files/jir-za-39-05-el-business-interuptioncovid.pdf

Dixon, L., and J. Morikawa (2021). Improving the Availability and Affordability of Pandemic Risk Insurance: Projected Performance of Proposed Programs. RAND. https://www.rand.org/pubs/research_reports/RRA1223-1.html

Hartwig, R., and R. Gordon (2020). Uninsurability of Mass Market Business Continuity Risks from Viral Pandemics. American Property Casualty Insurance Association. http://www.pciaa.net/docs/default-source/default-document-library/apcia-white-paper$\underline{\text { hartwig-gordon.pdf }}$ 
Kahneman, D., O. Siboney, and C. Sunstein (2021). Noise: A Flaw in Human Judgment. Little Brown, Spark.

Klein, R., and H. Weston (2020). Feasibility Questions About Government-Sponsored Insurance for Business Interruption Losses from Pandemics. Journal of Insurance Regulation 39(7): 1-19. https://content.naic.org/sites/default/files/jir-za-39-07-el-feasability-government.pdf

Knowles, S. G., and H. C. Kunreuther (2014). Troubled waters: The National Flood Insurance Program in historical perspective. Journal of Policy History, 26(3), 327-353.

Kousky, C., and H. Kunreuther (2018). Risk Management Roles of the Public and Private Sector. Risk Management and Insurance Review 21(1): 181-204.

Kunreuther, H., R. Hogarth, and J. Meszaros (1993). Insurer Ambiguity and Market Failure. Journal of Risk and Uncertainty 7: 71-87.

Kunreuther, H., M. Pauly, and S. McMorrow (2013). Insurance \& Behavioral Economics: Improving Decisions in the Most Misunderstood Industry. New York, NY: Cambridge University Press.

Kunreuther, H., and M. Useem (2021). Mastering Catastrophic Risk: How Companies Are Coping with Disruption. Oxford University Press.

Lloyd’s (2008). Pandemic Potential Insurance Impacts. October. https://assets.lloyds.com/media/3066455e-3231-46a7-9dea-e5c62bfaaf2d/pdf-pandemicpotential-insurance-impacts-er-pandemic-insuranceImpacts-v2.pdf

Lloyd's (2020). The Insurance Industry Response to COVID-19. October. https://uk.practicallaw.thomsonreuters.com/w-027-9436

Marsh (2020). Pandemic Risk Protection: Accelerate Recovery and Build Resilience Now Through Public-Private Partnership. June.

Meyer, R., and H. Kunreuther (2017). The Ostrich Paradox: Why We Underprepare for Disasters. Wharton School Press 
National Association of Insurance Commissioner (NAIC) (2021). Pandemic Business Interruption Insurance. Issue Brief. May. https://content.naic.org/sites/default/files/government-affairs-brief-pandemic-bi.pdf

Roth, R. J., Jr. (1998). Earthquake Insurance Protection in California. In: Paying the Price: The Status and Role of Insurance against Natural Disasters in the United States. (H.

Kunreuther and R. Roth, Sr., Eds.). Washington, DC: Joseph Henry Press, 67-95. 